\title{
Modem Device
}

National Cancer Institute

\section{Source}

National Cancer Institute. Modem Device. NCl Thesaurus. Code C50072.

An electronic device for converting between serial data from a computer and an audio signal suitable for transmission over a telephone line connected to another modem. 